\title{
REPRODUCTIVE AND DEVELOPMENTAL TOXICITY STUDY OF GADOBENATE DIMEGLUMINE FORMULATION (E7155) (2) - COMBINED STUDY OF EFFECTS ON FERTILITY AND EMBRYO-FETAL TOXICITY IN FEMALE RATS BY INTRAVENOUS ADMINISTRATION -
}

\author{
Takashi KAWAGUCHI ${ }^{1}$, Fumio SAGAMI ${ }^{1}$, Piero TIRONE ${ }^{2}$, Alberto MORISETTI ${ }^{2}$, \\ Simona BUSSI ${ }^{2}$ and Jane K. BAGULEY ${ }^{3}$ \\ 'Department of Developmental Safety Assessment Research, Eisai Co., Ltd. \\ I Takehaya, Kawashima-cho, Hashima-gun, Gifu 501-6195, Japan \\ ${ }^{2}$ Research Laboratories of Bracco S.p.A. \\ Via E. Folli, 50-20134 Milan, Italy \\ ${ }^{3}$ Huntingdon Life Sciences Ltd. \\ Eye, Suffolk IP23 7PX, England
}

(Received February 25, 1999; Accepted September 16, 1999)

\begin{abstract}
The influence of gadobenate dimeglumine formulation (E7155) on fertility and general reproductive performance and embryo-fetal development was assessed in female Sprague-Dawley rats. E7155 was administered by intravenous injection at a dose of $0.3,1.0$ or $2.0 \mathrm{mmol} / \mathrm{kg} /$ day to groups of 22 female rats for 15 days before pairing. Treatment was continued throughout mating and up to Day 17 of gestation. Control animals received $0.9 \%$ sterile physiological saline throughout the same period. All females were killed on Day 20 of gestation for examination of their uterine contents. There were no toxic clinical signs of treatment. The body weight and food consumption of females before pairing and during gestation were not affected by treatment. Estrous cycles, mating performance, litter size and fetal weight, survival and development were also not affected by treatment. Based on the above results, the No Observed Adverse Effect Level (NOAEL) of E7155 was $2.0 \mathrm{mmol} / \mathrm{kg} /$ day for general toxicologic effects and reproduction of female rats and the development of their fetuses.
\end{abstract}

KEY WORDS: Gadobenate dimeglumine formulation, E7155, Contrast agent for MRI imaging, Fertility, Teratology, Rat 


\section{ガドベン酸ジメグルミン製剤（E7155）の生殖発生毒性試験（第2報） 一雌性ラットにおける静脈内投与による受胎能および 胚・胎児発生に及ぼす影響に関する併合試験一 \\ 川口 隆1，佐神文郎1, Piero TIRONE ${ }^{2}$, Alberto MORISETTI², Simona BUSSI ${ }^{2}$ Jane K. BAGULEY ${ }^{3}$ \\ 【エーザイ株式会社 開発安全性研究部 \\ 厂501-6195 岐皁県羽島郡川島町竹早町1 \\ ${ }^{2}$ Research Laboratories of Bracco S.p.A. \\ Via E. Folli, 50-20134 Milan, Italy \\ ${ }^{3}$ Huntingdon Life Sciences Ltd. \\ Eye, Suffolk IP23 7PX, England}

要＼cjkstart約一受胎能㧍よび胚・胎児発生に及ぼすガドベン 酸ジメグルミン製剤（E7155）の影響について雌性SD ラットを用いて検討した。一群22匹の雌性ラットに0.3, 1.0 または $2.0 \mathrm{mmol} / \mathrm{kg} /$ 日のE7155を交配前 15 日間，静脈 内投与を行った。投与は交配中も継続し，娃娠17日ま で投与を行った。対照動物には同じ期間中 $0.9 \%$ 滅菌生 理食塩液を投与した。妊娠20日にすべての雌動物を屠 殺し，子宮内容物の検査を行った。

交配前㧍よび妊娠期間中の雌動物の体重増加量およ び摂餌量にはE7155投与による影響は認められなかっ た。発情周期，生殖能，同腹児数，胎児体重㧍よび妊 娠20日までの胎児の生存および発生には投薬による影 響は認められなかった。

以上の結果より，E71550雌動物の一般毒性学的無 毒性量，生殖能力㧍よび胎児の発生に対する無毒性量 は，いずれも $2.0 \mathrm{mmol} / \mathrm{kg} /$ 日と推察された。

\section{緒 言}

ガドベン酸ジメグルミン製剂（以下E7155と略）は， Bracco社（イタリア）により開発されたMRI（Magnetic Resonance Imaging, 磁気共鳴撮像法) で用いられる造 影剤である。

今回, E7155の安全性評価の一環として, 雌性ラッ 卜に抢ける静脈内投与による受胎能拉よび胚・胎児発 生に及ぼす影響に関する併合試験をHuntingdon Life Sciences社（イギリス）で実施したので報告する。

\section{実験材料および方法}

\section{被験物質}

E7155は，ガドベン酸ジメグルミン（化学名：1deoxy-1-(methylamino)-D-glucitol (RS)-dihydrogen [4carboxy-5,8,11-tris(carboxymethyl) -1-phenyl-2-oxa-5,8,11triazatridecan -13-oato(5-)] gadolinate (2-) (2:1), 分子量： 1058.16, 化学構造：Fig. 1) を $1 \mathrm{ml}$ 中に0.5 mmol含有す る無色一淡黄色の澄明な製剂（媒体：注射用水，中性 で生理食塩液に対する浸透圧：約7）である。本試験に はBracco社で製造されたロット番号B5/20（ガドベン酸 ジメグルミンの純度：99.1\%）を使用した。な㧍，被 験物質の投与量は, ガドベン酸ジメグルミンの量を表 記した。

\section{使用動物および飼育条件}

98匹のSprague-Dawley雌ラットをCharles River UK Ltd.（Kent,England）から購入し，5日間馴化飼育を行 い，健康状態が良好な動物を試験に供した。動物は室 温 $21^{\circ} \mathrm{C}$ (許容範囲 $19 \sim 25^{\circ} \mathrm{C}$ ), 相対湿度 $55 \%$ （許容範囲

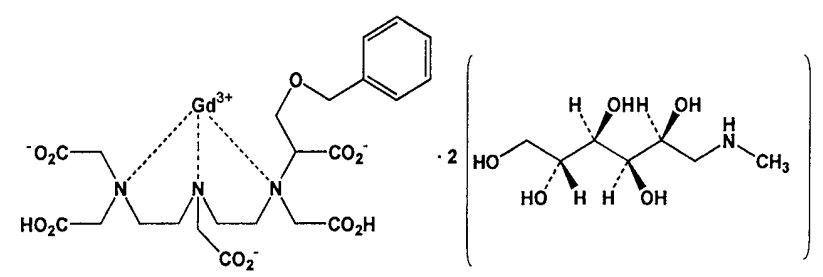

Fig. 1. Chemical structure of gadobenate dimeglumine. 
Combined Study on Fertility and Teratology of E7155 in Female Rats.

$40 \sim 70 \%)$, 換気回数 15 回以上/時間, 人工照明 12 時間/

日（午前6時〜午後6時）に設定された動物室で飼育し た。動物は，ステンレス製ケージ $(38 \times 54 \times 20 \mathrm{~cm})$ に は1ケージ当たり最高 5 匹まで飼育し，交尾後はステン レス製の網底付の高密度ポリプロピレン製ケージ（23.5X $39.5 \times 21.5 \mathrm{~cm})$ で個別飼育した。飼料は，げっ歯類用 固型飼料Laboratory Animal Diet No.1 SQC (Special Diet Services Ltd., Essex, England）を，飲水は上水道水をそ れぞれ自由に掑取させた。馿化後は，雌動物を5 gの体 重幅で区分し, 各体重区分から順次, 動物を選択して 群分けを行った。動物数は 1 群当たり 22 匹した。投与 開始時の雌動物は，約10〜11週齢で，体重は200〜237 g の範囲にあった。

\section{投与量および投与方法}

投与量は，ラットにおける静脈内投与による4週間 投与試験 (Aoki et al., 1999) の結果に抢いて3.0 mmol $/ \mathrm{kg} /$ 日 で投与部位である尾に顕著な湤皮㧍よび潰瘍が認めら れ投与できない日があったため, 本試験では $2.0 \mathrm{mmol} / \mathrm{kg} /$

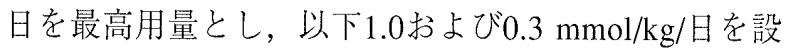
定した。投与容量はそれぞれ $4.0 \mathrm{ml} / \mathrm{kg} /$ 日， $2.0 \mathrm{ml} / \mathrm{kg} /$ 日 および $0.6 \mathrm{ml} / \mathrm{kg} /$ 日とし，対照群には $4.0 \mathrm{ml} / \mathrm{kg} /$ 日の $0.9 \%$ 生理食塩液を投与した。投与当日の体重に基づいて1匹 当たりの投与容量を算出した。投与期間は交配前15日 から交配期間を通して妊娠17日まで，尾静脈より約 $6 \mathrm{ml} /$ 分の速度で1日1回投与した。

\section{観察方法}

\section{1. 雌動物の観察}

一般状態の観察は每日行った。体重については投 与開始日㧍よび交尾が確認されるまでは週2回の間隔, 交尾成立後0日から18日まで毎日および20日に測定し た。摂餌量については，交配前は1週間の摂慨量を測定 し，交尾成立後は $0 \sim 2 ， 3 \sim 6 ， 7 \sim 9 ， 10 \sim 13 ， 14 \sim 17$, 18１9日の間の摂餌量をそれぞれ測定した。

発情周期については，交配前10日間にわたって腔垢 標本を作製し，発情周期のステージを分類して評価し た。

投与15日目に雌動物と無処置の雄動物を1対1で同居 させた。交尾の成立は每朝膣栓あるいは䐋垢中の精子 の存在により判定し，交尾が確認された日を娃娠 0 日と した。

\section{2. 帝王切開観察}

娃娠 20 日に二酸化炭素ガスの吸入により安楽死さ せた後, 生殖器を摘出し, 黄体数, 着床数, 子宮内の 胎児数㧍よび分布，胚・胎児死亡数を調べ，胎児の性 別㧍よび外表を観察し，個体別に胎児体重および胎盤 重量を測定した。また, 交尾成立動物の外表, 頸部, 胸腔, 腹腔, 骨盤腔および腔内の臟器・組織を観察し た。外見上の非妊娠動物については，Salewski (1964) の染色法により着床痕がないことを確認した。

\section{3．胎児検查}

胎児は約 $4{ }^{\circ} \mathrm{C} て ゙$ 冷却して安楽死させた。各同腹児の約 半数を新鮮状態での内藏検査を行った後, メ夕ノールで 固定し，アリザリンレッドで染色して骨格検査 (Dawson, 1926）を行った。残りの胎児はブアン液で固定し，フリ 一ハンド連続切片作製法 (Wilson, 1965) で内臟検査を 行った。胎児の形態変化は, 奇形, 異常㧍よび变異の3 つのカテゴリーに分類した。奇形はまれなものあるい は致死的である可能性の高いものとし，異常は比較的 高い頻度で検出される「正常」から軽度に相違するも の，変異は対照母集団に扔いて定期的に発現するよう な変化としてそれぞれ定義した。

\section{統計学的解析}

体重, 体重増加量, 摂餌量, 胎児体重掞よび胎盤重 量について有意差検定を行った。これらの検定は, 対照 群との群間比較に先立ち分散分析を実施した。投与群間 の分散（等分散あるいは不等分散）に応じて，パラメト リック検定として分散分析 (Snedecor and Cochran, 1967) とWilliams検定（Williams, 1971 and 1972）あるいはノンパ ラメトリック検定としてKruskal-Wallis検定 (Hollander and Wolfe, 1973）とShirley検定（Shirley, 1977）を用いた。性 比, 交尾成立期間, 黄体数, 着床数, 吸収肧数のデー 夕解析にはKruskal-Wallis検定の後にWilcoxon順位和検 定とShirley検定を用いた。同腹中の胎览奇形および異 常の頻度と分布のデー夕解析には線形連関検定 (Agresti, 1990; Agresti et al., 1990) と不均一性のデー夕に対 するKruskal-Wallis検定を用いた。統計学的に有意でな かった場合 $(\mathrm{p}>0.05$ 線形連関検定, $\mathrm{p}>0.01$ KruskalWallis検定）には更なる解析は実施しなかった。線形

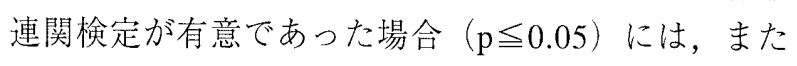
Kruskal-Wallis検定が有意でない場合には，線形連関検

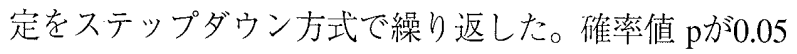




\section{T. KAWAGUCHI et al.}

未満である場合を有意と判定した。

\section{実験結果}

\section{雌動物に及ぼす影響}

\section{1. 死亡およびー般状態}

$2.0 \mathrm{mmol} / \mathrm{kg} /$ 日群の1匹で妊娠 12 日に死亡した。剖 検を行った結果，胸腺の肥大およびうっ血が認められ た。それ以外には死亡動物はなかった。 $1.0 \mathrm{mmol} / \mathrm{kg} /$ 日
群の2匹および $2.0 \mathrm{mmol} / \mathrm{kg} /$ 日群の6匹において投与部位 に軽微な局所紅斑が認められ，2.0 mmol/ $\mathrm{kg} /$ 日群の4匹 では投与部位に挫傷，剥脱，痂皮形成を含む顕著な局 所損傷も認められたが，これら以外に一般状態の変化 は認められなかった。

\section{2. 体重および摂䬣量}

交配前15日間および妊娠期間中の体重と摂餌量を Table 1に示した。交配前㧍よび妊娠中の体重と摂慨量

Table 1. Body weights and food consumption of female rats treated with E7155.

\begin{tabular}{|c|c|c|c|c|}
\hline Dose (mmol/kg/day) & 0 & 0.3 & 1.0 & 2.0 \\
\hline \multicolumn{5}{|l|}{ Body weights (g) } \\
\hline No. of females & 22 & 22 & 22 & 22 \\
\hline \multicolumn{5}{|l|}{ Premating period (day) } \\
\hline 0 & $224 \pm 8$ & $222 \pm 9$ & $223 \pm 7$ & $222 \pm 8$ \\
\hline 3 & $226 \pm 9$ & $229 \pm 10$ & $229 \pm 8$ & $229 \pm 8$ \\
\hline 7 & $231 \pm 12$ & $235 \pm 12$ & $235 \pm 11$ & $233 \pm 10$ \\
\hline 10 & $235 \pm 13$ & $240 \pm 13$ & $239 \pm 11$ & $238 \pm 11$ \\
\hline 14 & $241 \pm 14$ & $246 \pm 15$ & $246 \pm 12$ & $243 \pm 12$ \\
\hline $0-3$ & $2 \pm 4$ & $7 \pm 5$ & $6 \pm 5$ & $6 \pm 3$ \\
\hline $0-14$ & $18 \pm 9$ & $24 \pm 9$ & $23 \pm 8$ & $21 \pm 10$ \\
\hline No. of pregnant females & 22 & 22 & 22 & 21 \\
\hline No. of pregnant females dead & 0 & 0 & 0 & 1 \\
\hline \multicolumn{5}{|l|}{ Gestation period (day) } \\
\hline 0 & $248 \pm 13$ & $252 \pm 12$ & $251 \pm 13$ & $251 \pm 12$ \\
\hline 1 & $257 \pm 14$ & $261 \pm 13$ & $259 \pm 12$ & $258 \pm 11$ \\
\hline 6 & $277 \pm 16$ & $283 \pm 15$ & $283 \pm 15$ & $279 \pm 13$ \\
\hline 12 & $304 \pm 19$ & $310 \pm 20$ & $311 \pm 17$ & $306 \pm 13$ \\
\hline 18 & $360 \pm 25$ & $372 \pm 22$ & $368 \pm 23$ & $365 \pm 14$ \\
\hline 20 & $392 \pm 29$ & $406 \pm 24$ & $400 \pm 26$ & $398 \pm 16$ \\
\hline $0-6$ & $30 \pm 5$ & $30 \pm 6$ & $32 \pm 6$ & $28 \pm 5$ \\
\hline $6-12$ & $26 \pm 7$ & $28 \pm 6$ & $28 \pm 6$ & $27 \pm 6$ \\
\hline $12-18$ & $56 \pm 10$ & $61 \pm 6$ & $57 \pm 10$ & $57 \pm 10$ \\
\hline $18-20$ & $32 \pm 9$ & $34 \pm 5$ & $32 \pm 5$ & $33 \pm 8$ \\
\hline \multicolumn{5}{|l|}{ Food consumption } \\
\hline No. of cages & 5 & 5 & 5 & 5 \\
\hline \multicolumn{5}{|c|}{ Premating period (week : g/rat/week) } \\
\hline 1 & $125 \pm 8$ & $131 \pm 8$ & $128 \pm 5$ & $127 \pm 5$ \\
\hline 2 & $126 \pm 4$ & $129 \pm 9$ & $128 \pm 4$ & $128 \pm 5$ \\
\hline No. of pregnant females & 22 & 22 & 22 & 21 \\
\hline \multicolumn{5}{|c|}{ Gestation period (day : g/rat/day) } \\
\hline $0-2$ & $25 \pm 2$ & $26 \pm 3$ & $26 \pm 2$ & $26 \pm 2$ \\
\hline 3- 6 & $27 \pm 3$ & $27 \pm 3$ & $27 \pm 2$ & $27 \pm 2$ \\
\hline $7-9$ & $27 \pm 2$ & $28 \pm 3$ & $27 \pm 3$ & $27 \pm 2$ \\
\hline $10-13$ & $29 \pm 3$ & $30 \pm 3$ & $29 \pm 2$ & $29 \pm 2$ \\
\hline $14-17$ & $29 \pm 2$ & $31 \pm 2$ & $30 \pm 2$ & $30 \pm 2$ \\
\hline $18-19$ & $29 \pm 2$ & $30 \pm 3$ & $30 \pm 2$ & $30 \pm 2$ \\
\hline
\end{tabular}

Values represent mean \pm S.D. 
Combined Study on Fertility and Teratology of E7155 in Female Rats.

はE7155のいずれの投与群も対照群との間に差は認め られなかった。

\section{3. 発情周期}

交配前の発情周期をTable 2に示した。全群の大多 数の雌動物の発情周期は4日間あるいは5日間の規則的 周期を呈していたが， $2.0 \mathrm{mmol} / \mathrm{kg} /$ 日群では，対照群 に比して4日間の発情周期を示す雌動物数が有意に少な く $(\mathrm{p}<0.05)$ ，それに伴って，4日間および5日間の周 期を示す雌動物数がわずかに多かった。さらに，この 投与量では無発情の雌動物（少なくとも10日間無発情） が2匹認められた。

\section{4.交尾能および受胎能}

交配成績をTable 3に示した。全群全動物で交尾が 認められ，交尾率は100\%であった。受胎率は95～100\% の範囲であり，対照群とE7155の各投与群との間に有 意な差は認められなかった。

\section{帝王切開所見}

帝王切開時の観察結果をTable 4に示した。黄体数, 着床数, 生存胎児数, 吸収肧数, 着床前および着床後 死亡の頻度，胎児体重，胎盤重量のいずれにおいても 対照群とE7155の各投与群との間に有意な差は認めら れなかった。胎児外表においても，E7155に起因した 異常は認められなかった。また，妊娠動物において E7155に起因した肉眼的異常は認められなかった。

\section{胎児の内臓および骨格観察}

胎児の内臓および骨格観察の結果をTable 5および Table 6のそれぞれに示した。奇形として， $0.3 \mathrm{mmol} / \mathrm{kg} /$ 日群の1例に右網膜㱀壁， $1.0 \mathrm{mmol} / \mathrm{kg} /$ 日群の1例に第 1 左側および第6右側頸椎弓の小型化， $2.0 \mathrm{mmol} / \mathrm{kg} /$ 日群 の1例に横隔膜ヘルニアが認められたが，対照群に比べ E7155投与群で有意な増加を示す奇形は認められなか った。その他の形態変化である内臓異常（新鮮標本観 察，ブアン固定後観察) 並びに骨格異常および変異に おいて，対照群とE7155の各投与群との間に発現数の 有意な差は認められなかった。

\section{考察}

雌ラットにE7155を $0.3,1.0,2.0 \mathrm{mmol} / \mathrm{kg} /$ 日の投与 量で交配前15日から交配期間を経て妊娠17日まで静脈 内投与した。

Table 3. Mating performance and fertility of female rats treated with E7155.

\begin{tabular}{lcccc}
\hline Dose (mmol/kg/day) & 0 & 0.3 & 1.0 & 2.0 \\
\hline No. of paired & 22 & 22 & 22 & 22 \\
No. of mating & 22 & 22 & 22 & 22 \\
Pre-coital interval (days) & 3.0 & 2.5 & 2.6 & 2.9 \\
Copulation rate (\%) & 100 & 100 & 100 & 100 \\
No. of pregnant & 22 & 22 & 22 & 21 \\
Conception rate (\%) & 100 & 100 & 100 & 95 \\
\hline
\end{tabular}

Table 2. Estrous cycles of female rats treated with E7155.

\begin{tabular}{|c|c|c|c|c|}
\hline Dose (mmol/kg/day) & 0 & 0.3 & 1.0 & 2.0 \\
\hline No. of animals examined & 22 & 22 & 22 & 22 \\
\hline \multicolumn{5}{|l|}{ Regular cycles } \\
\hline 4 day $(\%)$ & $20(91)$ & $20(91)$ & $21(95)$ & $13 *(59)$ \\
\hline $4 / 5$ day $(\%)$ & $1(5)$ & $2(9)$ & $0(0)$ & $7(32)$ \\
\hline 5 day $(\%)$ & $1(5)$ & $0(0)$ & $1(5)$ & $0(0)$ \\
\hline Irregular cycle \# & 0 & 0 & 0 & 0 \\
\hline Acyclic $^{\# \#}(\%)$ & 0 & 0 & 0 & $2(9)$ \\
\hline
\end{tabular}

Values represent number of animals in category.

* : Significantly different from control, $\mathrm{p}<0.05$ (Fisher's exact test).

\# : At least one cycle of two, three or six to ten days.

\#\# : At least ten days without estrus. 
T. KAWAGUCHI et al.

Table 4. Cesarean section data of pregnant rats treated with E7155.

\begin{tabular}{lcccc}
\hline Dose (mmol/kg/day) & 0 & 0.3 & 1.0 & 2.0 \\
\hline No. of litters & 22 & 22 & 22 & 20 \\
No. of corpora lutea & $15.9 \pm 2.7$ & $16.3 \pm 1.4$ & $15.8 \pm 2.1$ & $16.9 \pm 1.3$ \\
No. of implantations & $15.4 \pm 2.5$ & $15.7 \pm 1.6$ & $14.9 \pm 1.8$ & $15.4 \pm 1.2$ \\
No. of resorptions & & & & \\
$\quad$ Early & $1.14 \pm 1.07$ & $0.59 \pm 0.77$ & $0.77 \pm 0.88$ & $1.00 \pm 1.00$ \\
$\quad$ Late & $0.00 \pm 0.00$ & $0.05 \pm 0.21$ & $0.00 \pm 0.00$ & $0.00 \pm 0.00$ \\
$\quad$ Total & $1.14 \pm 1.07$ & $0.64 \pm 0.80$ & $0.77 \pm 0.88$ & $1.00 \pm 1.00$ \\
Pre - implantation loss (mean \%) a) & 3.9 & 3.3 & 6.5 & 8.4 \\
Post - implantation loss (mean \%) & 8.0 & 4.1 & 5.1 & 6.6 \\
No. of live fetuses & $14.3 \pm 3.7$ & $15.1 \pm 1.8$ & $14.1 \pm 2.0$ & $14.4 \pm 2.3$ \\
Sex ratio (\% males) & 44.1 & 57.2 & 43.9 & 52.3 \\
Fetal weights (g) & & & $3.83 \pm 0.26$ & $3.85 \pm 0.26$ \\
$\quad$ Male & $3.77 \pm 0.23$ & $3.87 \pm 0.16$ & $3.60 \pm 0.25$ & $3.64 \pm 0.23$ \\
$\quad$ Female & $3.57 \pm 0.26$ & $3.68 \pm 0.16$ & $0.53 \pm 0.04$ & $0.57 \pm 0.17$ \\
Placental weights (g) & $0.55 \pm 0.07$ & $0.54 \pm 0.05$ & 1 & 0 \\
No. of fetuses with shiny skin & 1 & & 1 & 2 \\
\hline
\end{tabular}

Values represent mean \pm S.D.

a) $[$ (No. of corpora lutea - No. of implantations) / No. corpora lutea $] \times 100$.

b) $[$ (No. of implantations - No. of live fetuses $) /$ No. of implantations $] \times 100$.

Table 5. Visceral findings of rat fetuses.

\begin{tabular}{|c|c|c|c|c|}
\hline Dose (mmol/kg/day) & 0 & 0.3 & 1.0 & 2.0 \\
\hline No. of fetuses (litters) examined (fresh) & $157(22)$ & $167(22)$ & $154(22)$ & $144(20)$ \\
\hline \multicolumn{5}{|l|}{ No. of fetuses (litters) with malformations } \\
\hline Diaphragmatic hernia & 0 & 0 & 0 & 1( 1$)$ \\
\hline \multicolumn{5}{|l|}{ No. of fetuses (litters) with anomalies } \\
\hline Renal cavitation & $9(7)$ & $14(10)$ & 17(11) & $13(6)$ \\
\hline Hydroureter & $3(3)$ & $6(6)$ & $11(8)$ & $12(6)$ \\
\hline No. of fetuses (litters) examined (fixed) & $157(22)$ & $165(22)$ & $157(22)$ & $144(20)$ \\
\hline \multicolumn{5}{|l|}{ No. of fetuses (litters) with malformations } \\
\hline Right retinal fold & 0 & 1( 1$)$ & 0 & 0 \\
\hline \multicolumn{5}{|l|}{ No. of fetuses (litters) with anomalies } \\
\hline \multicolumn{5}{|l|}{ Hemorrhages } \\
\hline Brain/spinal cord & $3(2)$ & $6(5)$ & $2(2)$ & $3(2)$ \\
\hline Eye/surrounding tissue & 0 & 0 & 1( 1$)$ & 0 \\
\hline Subcutaneous & 2( 2) & 6( 4) & $1(1)$ & $4(3)$ \\
\hline Other dorsal fat pad & 0 & 1( 1$)$ & 0 & 0 \\
\hline intra abdominal & 1( 1$)$ & 2( 2) & $3(2)$ & 0 \\
\hline within liver & 1( 1$)$ & $3(3)$ & $4(4)$ & $3(2)$ \\
\hline Absent innominate artery & 0 & 1( 1$)$ & 0 & 0 \\
\hline Interventicular septal defect (small) & 0 & 0 & 0 & 1( 1$)$ \\
\hline Kidney(s) rudimentary/absent papilla & 1( 1$)$ & 1( 1$)$ & 2( 2) & 2( 2) \\
\hline Ureter(s) dilated & $6(4)$ & 3( 3) & $3(3)$ & 1( 1$)$ \\
\hline Eyes(s) & 1( 1$)$ & 0 & 0 & 0 \\
\hline rudimentary & 0 & 0 & 0 & $1(1)$ \\
\hline undecended horn & 0 & 1( 1$)$ & 0 & 0 \\
\hline Diaphragm thin with protruding liver & $3(3)$ & $2(2)$ & $4(4)$ & $3(3)$ \\
\hline \multirow{3}{*}{$\begin{array}{cc}\text { Liver } & \text { additional lobe } \\
\text { pale area } \\
\text { Testis(es) } & \text { displaced }\end{array}$} & 0 & 3( 3) & 0 & 0 \\
\hline & 0 & 0 & 0 & 1( 1$)$ \\
\hline & $5(4)$ & $5(5)$ & $5(4)$ & $8(6)$ \\
\hline
\end{tabular}

Values represent number of affected fetuses. 
Combined Study on Fertility and Teratology of E7155 in Female Rats.

母動物においてて, $2.0 \mathrm{mmol} / \mathrm{kg} /$ 日群の1匹が妊娠 12 日 に死亡した。この動物の剖検では胸腺の肥大およびう つ血が認められたのみであった。この死亡動物は投与 前の一般状態に異常は認められず，同投与量を投与さ れたラットの催奇形性試験 (未発表) および $3.0 \mathrm{mmol} / \mathrm{kg}$ / 日が投与されたラットの4週間反復投与毒性試験 (Aoki et al., 1999) では投薬に起因した死亡は認められていな いことから，今回の死亡は投薬との関連性はなく，偶 発的なものと推察された。 $1.0 \mathrm{mmol} / \mathrm{kg}$ 日群および 2.0 $\mathrm{mmol} / \mathrm{kg} /$ 日群で投与部位に局所刺激性変化が認められ た。この変化は本剂の高浸透圧と大量投与によるもの
であり，通常の毒性試験の毒性変化に該当しないと考 えられ，毒性評価から除外した。その他，一般状態， 体重，掑餌量および剖検において投薬の影響は認めら れなかった。

生殖機能に関しては，2.0 mmol $/ \mathrm{kg} /$ 日群で性周期の延 長が示唆された。しかしながら, 本試験の対照群で4 日 間周期の動物の出現頻度 $(91 \%)$ が背景対照データ (50〜 $86 \%)$ を越えており，2.0 mmol/ $/ \mathrm{kg} /$ 日群の出現頻度 $(59 \%)$ は背景対照デー夕の範囲内であったことから，2.0 $\mathrm{mmol} / \mathrm{kg} /$ 日群の発情周期の延長は投薬との関連性はな いと考えられた。更に，踓動物の受胎能および妊娠状

Table 6. Skeletal findings of rat fetuses.

\begin{tabular}{|c|c|c|c|c|c|}
\hline \multicolumn{2}{|l|}{ Dose $(\mathrm{mmol} / \mathrm{kg} / \mathrm{day})$} & 0 & 0.3 & 1.0 & 2.0 \\
\hline \multicolumn{2}{|c|}{ No. of fetuses (litters) examined } & $157(22)$ & $167(22)$ & $154(22)$ & 144(20) \\
\hline \multicolumn{6}{|c|}{ No. of fetuses (litters) with malformations } \\
\hline \multicolumn{2}{|c|}{$\begin{array}{l}\text { Small 1st left and 6th right cervical } \\
\text { vertebral arches }\end{array}$} & 0 & 0 & 1( 1) & 0 \\
\hline \multicolumn{6}{|c|}{$\begin{array}{l}\text { No. of fetuses (litters) with anomalies } \\
\text { Incomplete ossification }\end{array}$} \\
\hline \multicolumn{6}{|c|}{ centers } \\
\hline \multirow[t]{3}{*}{ Vertebrae } & cervical & 0 & 0 & 3( 3 ) & $6(2)$ \\
\hline & thoracic/lumbar & 2( 2) & $4(3)$ & $5(5)$ & $5(5)$ \\
\hline & sacrocaudal & $4(2)$ & 6( 3$)$ & $12(7)$ & $5(4)$ \\
\hline \multicolumn{2}{|c|}{ Ischial bones } & $2(2)$ & $2(2)$ & $2(2)$ & $4(2)$ \\
\hline \multirow{2}{*}{\multicolumn{2}{|c|}{ Pubic bones }} & 3( 1$)$ & $3(2)$ & $4(3)$ & $3(2)$ \\
\hline Metacarpal & & 0 & 0 & 1( 1$)$ & $1(1)$ \\
\hline \multicolumn{6}{|c|}{ Precocious ossification } \\
\hline \multicolumn{2}{|c|}{ Cervical vertebral center } & 2( 1$)$ & $5(5)$ & $7(5)$ & $5(5)$ \\
\hline \multicolumn{6}{|c|}{ Other abnormalities } \\
\hline Cranial & bone plaque & $1(1)$ & $1(1)$ & $1(1)$ & 1( 1$)$ \\
\hline Vertebral & $\begin{array}{l}\text { dumbbell/bipartite } \\
\text { asmmetrically ossified } \\
\text { centrum }\end{array}$ & $2(2)$ & $7(5)$ & $3(3)$ & $9(7)$ \\
\hline Ribs & short & 0 & 0 & 0 & 1( 1$)$ \\
\hline Sternebrae & offset/bipartite & 0 & 0 & 2(2) & $1(1)$ \\
\hline Tail & short & 0 & 0 & 1( 1$)$ & 0 \\
\hline \multicolumn{6}{|c|}{ Rib/vertebral configuration } \\
\hline \multicolumn{2}{|c|}{20 thoracolumbar vertebrae } & $1(1)$ & 0 & $1(1)$ & 0 \\
\hline Offset pelv & & 1( 1$)$ & 0 & 1( 1$)$ & $1(1)$ \\
\hline \multicolumn{6}{|c|}{ No. of fetuses (litters) with variants } \\
\hline \multicolumn{2}{|c|}{ No. of fetuses with 13 ribs } & $136(22)$ & $160(22)$ & $140(22)$ & $126(20)$ \\
\hline \multicolumn{2}{|c|}{$\begin{array}{l}\text { No. of fetuses with } 13 / 14 \text { or } 14 / 14 \text { ribs } \\
\text { (mean \%) }\end{array}$} & $\begin{array}{l}21(10) \\
(13.4)\end{array}$ & $\begin{array}{l}7(6) \\
(4.2)\end{array}$ & $\begin{aligned} 14(9) \\
(9.7)\end{aligned}$ & $\begin{array}{l}18(7) \\
(12.1)\end{array}$ \\
\hline \multicolumn{2}{|c|}{$\begin{array}{l}\text { No. of fetuses with incomplete ossification } \\
5 \text { th/6th sternebrae }\end{array}$} & $100(20)$ & $100(21)$ & $97(22)$ & $78(19)$ \\
\hline \multicolumn{2}{|c|}{$\begin{array}{l}\text { No. of fetuses with incomplete ossification } \\
\text { other sternebrae }\end{array}$} & $2(2)$ & $5(3)$ & $7(5)$ & $1(1)$ \\
\hline \multicolumn{2}{|c|}{$\begin{array}{l}\text { Total No. of affected fetuses } \\
\text { (mean \%) }\end{array}$} & $\begin{array}{l}100(20) \\
(61.5)\end{array}$ & $\begin{array}{l}100(21) \\
\quad(59.4)\end{array}$ & $\begin{array}{l}97(22) \\
(63.8)\end{array}$ & $\begin{array}{l}78(19) \\
(56.0)\end{array}$ \\
\hline
\end{tabular}

Values represent number of affected fetuses. 


\section{T. KAWAGUCHI et al.}

態並びに胎児の生存，体重および形態に対して投薬に よる影響は認められなかった。一方，類薬であるガド ペンテト酸メグルミンを腹腔内投与したラットの妊娠 前㧍よび妊娠初期投与試験（児玉ら，1987a）では雙動 物の生殖能力および次世代への影響は認められていな いが，静脈内投与したラットの器官形成期投与試験 （児玉ら，1987b）では高用量で肧胎児死亡率の増加お よび化骨進行度の遅延が認められている。

以上の結果より, 本剤の毒性は認妨られなかったが, 技術的に連続投与が可能である $2.0 \mathrm{mmol} / \mathrm{kg} /$ 日を最高用 量として設定しており，予定臨床用量 $(0.1 \mathrm{mmol} / \mathrm{kg} /$ 日) の20倍であるため，十分な暴露量により毒性の全容を 把握することができたと考えられた。したがって， E7155の妊娠動物に扔ける一般毒性学的無毒性量, 生 殖能力㧍よび胎览の発生に対する無毒性量は，いずれ も $2.0 \mathrm{mmol} / \mathrm{kg} /$ 日と推察された。

\section{参考文献}

Agresti, A. (1990) : Categorical data analysis. John Wiley \& Sons, New York.

Agresti, A., Mehta, C.R. and Patel, N.R. (1990) : Exact inference for contingency tables with ordered categories. JASA, 85, 452-458.

Aoki, T., Sagami, F., Tirone, P., Moresetti, A., Bussi, S. and Masters, R. E. (1999) : General toxicity of gadobenate dimeglumine formulation (E7155) (3) -4-week repeated dose intravenous toxicity syudy followed by 4-week recovery period in rats-., J. Toxicol. Sci., 24 Suppl. I, 19-39 (in Japanese).

Dawson, A.B. (1926): A note on the staining of the skeletal of cleared specimens with Alizarin Red S. Stain Technol, 1,
123-124.

Hollander, M. and Wolfe, D.A. (1973) : Non-parametric statistical methods. pp. 68-75 and 114-132, J. Wiley \& Sons, New York.

児玉直己, 川崎知子, 加藤和恵, 占部圭子, 岡田智美, 中尾寿夫 (1987a) : ガドペンテト酸メグルミンの 生殖試験（I）-ラットの妊娠前および妊娠初期 投与試験一. 日獨医報, 32, 502-510.

児玉直己，占部圭子，岡田智美，加藤和恵，中尾寿夫 (1987b)：ガドペンテト酸メグルミンの生殖試験 (II) 一ラットの器官形成期投与試験一. 日獨医報, 32, 511-525.

Salewski, E. (1964): Färbemethode zum makroskopischen Nachweis von implantationsstellen am Uterus der Ratte. Naunyn-Schmiedebergs Arch. Exp. Pathol Pharmacol. 247, 367.

Shirley, E. (1977) : A non-parametric equivalent of Williams' test for contrasting increasing dose levels of a treatment. Biometrics, 33, 386-389.

Snedecor, G.W. and Cochran, W.G. (1967) : Statistical Methods. $6^{\text {th }}$ ed. The Iowa State University Press, U.S.A.

Williams, D.A. (1971) : A test for differences between treatment means when several dose levels are compared with a zero dose contorol Biometrics, 27, 103-117.

Williams, D.A. (1972) :The comparison of several dose levels with a zero dose control. Biometrics, 28, 519-531.

Wilson, J.G.(1965) : Methods for administering agents and detecting malformations in experimental animals. In: Teratology: Principles and Techniques (Wilson, J.G. and Warkany, J. eds.), pp. 262-277, University of Chicago Press, Chicago. 